\title{
Analysis of Indoor Air Quality in a Naturally Venti- lated University Building, Determination of an In- door Air Quality Indicator
}

\author{
Alžběta Kohoutková ${ }^{1}$, Karel Kabele ${ }^{2}$, \\ ${ }^{1}$ University Centre for Energy Efficient Buildings, Czech Technical University in Prague, \\ ${ }^{2}$ Czech Technical University in Prague
}

\begin{abstract}
The indoor environment is characterized by thermal comfort, indoor air quality, lighting, acoustics and others components. A pilot study was performed in order to figure out a ventilation indicator. The study is focused on the search for the indicator, which can specify a minimum ventilation rate for office buildings and school buildings. How should ventilation system control perform - based on which pollutant? In the indoor air, there are many pollutants which might be subject of investigation. The study continues and develops the results of Clear - up project implemented at the CTU during years 2008 - 2012. The indoor air quality is analysed and evaluated in an office building of a university based on the concentration measurements of chemical pollutants. The office building envelope has been recently retrofitted.
\end{abstract}

The paper is focused on the question how the IAQ in an office is influenced by a natural ventilation rate and by a new retrofitted facade. The comparison of Czech, German and World Health Organization (WHO) standards is included. The main results are expressed by percentage frequency of the measured concentrations divided by permissible exposure limits (PELs). The aim of the manuscript is to find an indicator for a naturally ventilated office. The measurements were carried out in November and December 2014. The selected pollutants were measured: total volatile organic compounds TVOC, carbon dioxide and formaldehyde. The measurements were carried out in three different standpoints. These standpoints were specially chosen in order to describe IAQ in the whole office and anticipate non-uniformity in pollutants distribution. The $\mathrm{SF}_{6}$ tracer gas was used to determine air change rate. The measurements were carried out by a photoacoustic field gas monitor. Its measurement principle is based on the photoacoustic infrared detection method. The concentration decay method was used to determine the air change rate via natural ventilation through the building envelope. The air change through building envelope was calculated according to $\mathrm{SF}_{6}$ concentration and the air changes according to some selected pollutants were calculated. The boundary outdoor conditions were taken from measurements made by the Czech Hydro Meteorological Institute (CHMU) and the National Institute for Public Health (SZU) for the city of Prague location. The air change values were given in a table. The manuscript showed the IAQ indicator. The paper shows the importance of boundary conditions (outdoor pollution conditions and indoor equipment) of the IAQ calculations and measurements. The manuscript is intended to generalize the obtained results. According to the standard [7], the ventilation rate is supposed to be $0.1 \mathrm{1} / \mathrm{h}$. The ventilation rate through the facade and building envelope is $0.108 \mathrm{1} / \mathrm{h}$ but it is not sufficient. The sufficient ventilation rates were calculated according to different pollutants to the values 0.123 and 0.129 and 0.120 . The ideal value is $0.13 \mathrm{1} / \mathrm{h}$.
Keywords - Air change, indoor air quality, IAQ measurement and analysis, natural ventilation, TVOC, ventilation indicator.

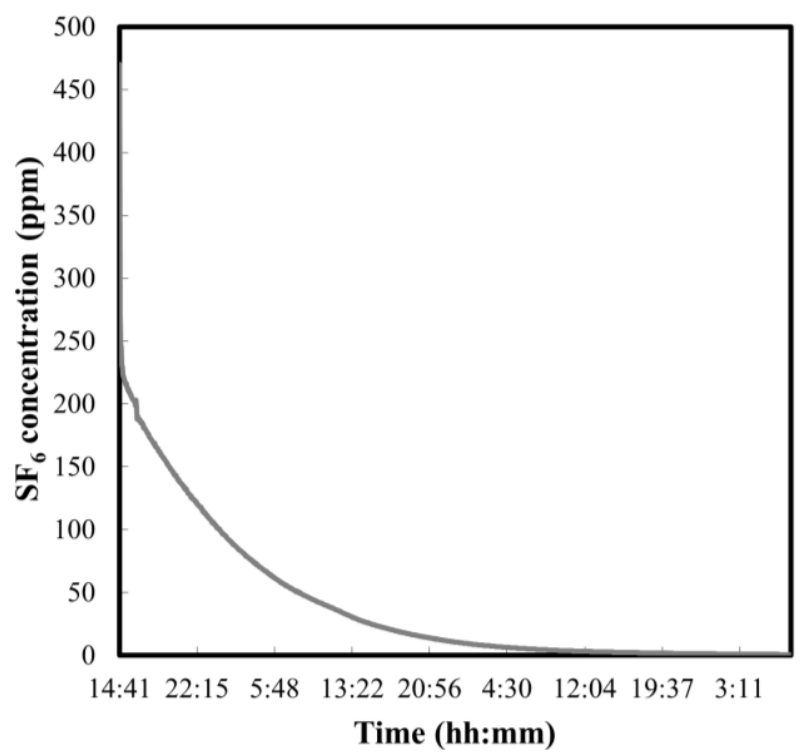

Fig. 1. $\mathrm{SF}_{6}$ concentration monitor standpoint.
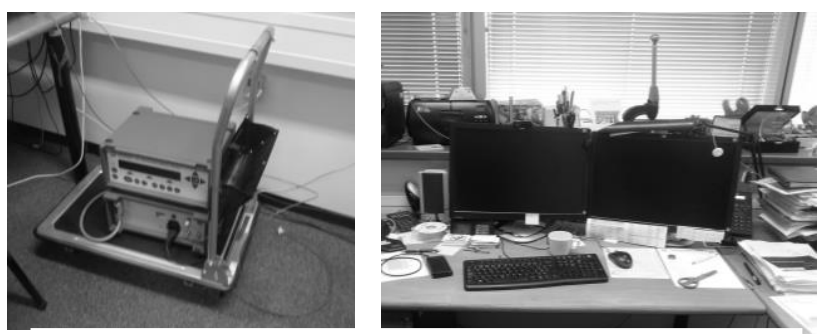

Fig. 2,3. Images of Innova device and measurement controls.

\section{INTRODUCTION}

According to the last trends of energy savings in building services operation and building envelope insulation, the minimum air change rate is calculated considering heat retention. Ventilation system control is usually based on the $\mathrm{CO}_{2}$ measured concentration. When there is just natural ventilation in a room, we are not able to control the air change rate. The air change rate is dependent on the occupant behavior. This paper 
is focused on experimental description of the investigated pollutants in a naturally ventilated room

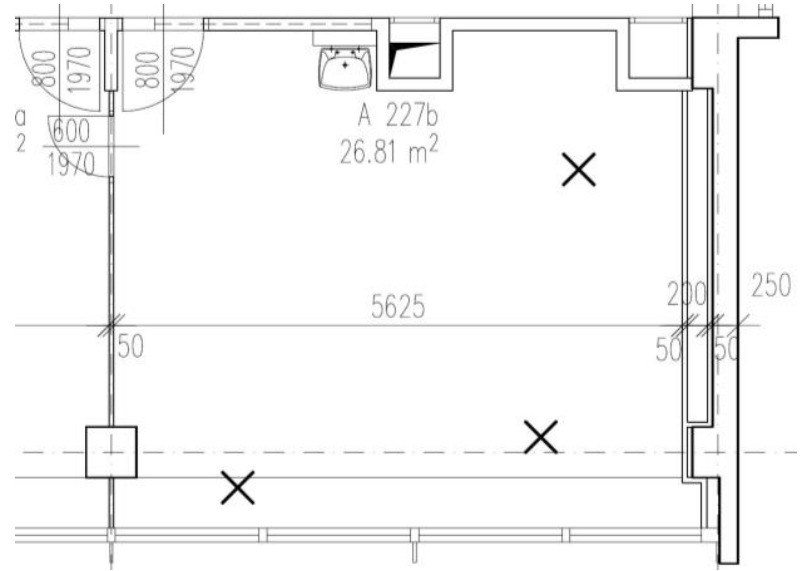

Fig. 4. Layout of the investigated office with three measured arbitrary points.

without occupants. The aim of the paper is to determine the most important pollutant to specify ventilation requirements.

\section{MEASUREMENT}

The measurement was carried out by Innova 1412 device (Fig. 2, 3). This device works on the photoacoustic spectroscopy principle. The following gases were measured: formaldehyde, carbons dioxide and monoxide, TVOC and water vapour. The measurement was carried out in three places in the room at the same time - at the windowsill, on the computer monitor and in the stand with a projection screen. The three places (Fig. 4) were chosen where it was possible to obtain three different results according to the ventilation results. The best results were supposed to be at the windowsill, rather than on the monitor and the worst in the stand of a projection screen. [1], [2]

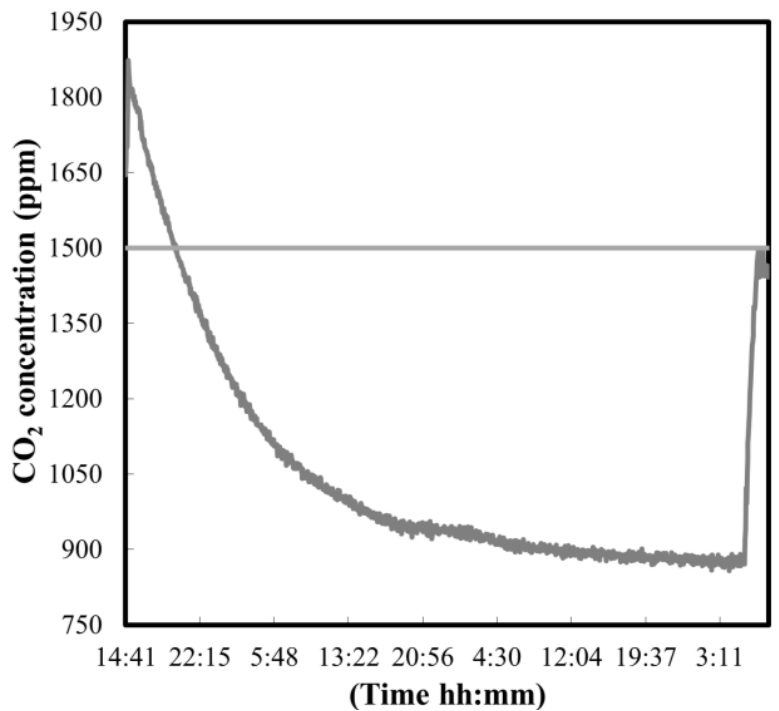

Fig. 5. $\mathrm{CO}_{2}$ concentration monitor standpoint.

\section{A. Ventilation of the investigated room}

The room was ventilated before the measurement for half an hour. The ventilation was natural by an opened window. On Friday, the door was opened a few times when the occupant came in and out of the investigated room. During the weekend the ventilation was carried out only by infiltration.

The ventilation rate calculation through the renovated wall and through the windows was made in line with the following equation: [3]

$$
\frac{\int_{0}^{\infty} C(\tau) \mathrm{d} \tau}{C(0)}
$$

$\mathrm{C}(\infty)=$ measured concentration at $\tau=\infty$

$\mathrm{C}(0)$ - measured concentration at $\tau=0$

$\tau=$ time of measurement

On Monday morning, the office hours started and occupants were present. The air change from Friday 3:41 pm to Monday 9:11 am was calculated from the $\mathrm{SF}_{6}$ tracer gas concentrations measurement (Fig. 1). The air change was $0.1081 / \mathrm{h}$.

\section{B. The course of the concentration of pollutants during the meas- urement}

The following gasses are considered: formaldehyde, TVOC and carbon dioxide. In Fig. 6 there is a course of concentration of formaldehyde. The limit of detection of this device for formaldehyde measurement is 0.04 or 0.1 according to the filter type. During the measurement, the measured values are close to the limit of detection.

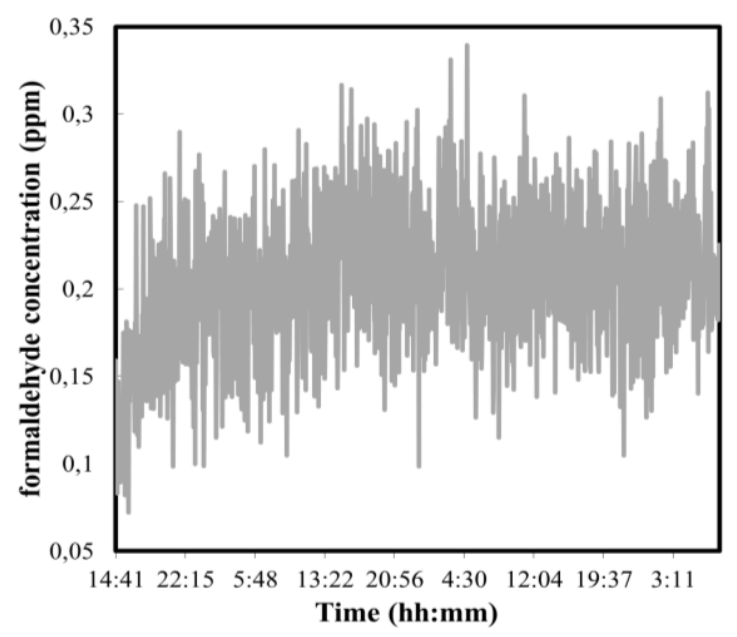

Fig. 6. Formaldehyde concentration monitor standpoint.

In the beginning, the effect of ventilation is visible. The next course of formaldehyde is not dependent on occupant presence. Wood paneling and carpets are the source of formaldehyde inside the building. 


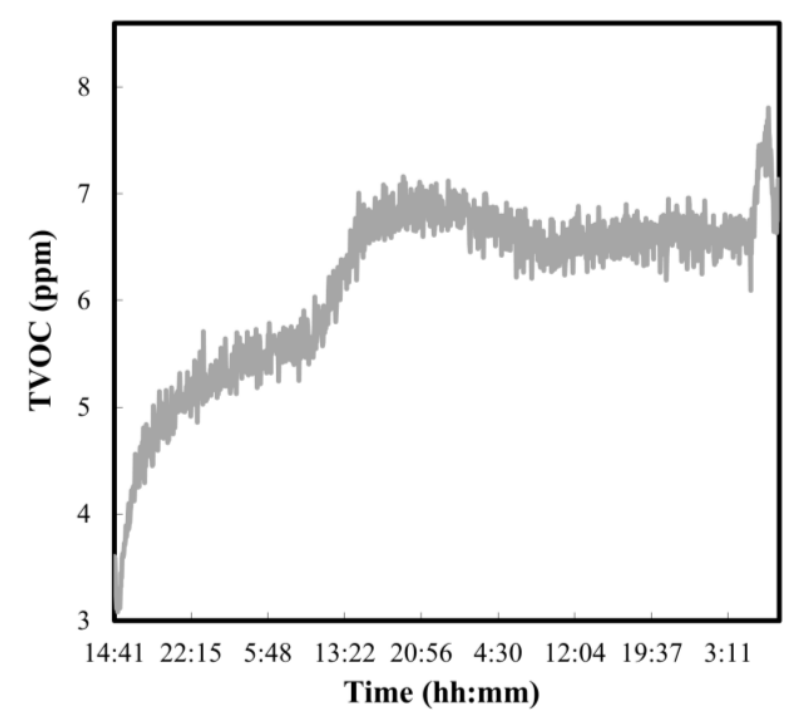

Fig. 7. TVOC concentration monitor standpoint.

The course of the TVOC concentration (Fig. 7) is influenced by the effect of ventilation in the beginning. The level of TVOC settles down to the values $6.5-7 \mathrm{ppm}$. On Monday

in the office hours the level of TVOC rose to $8 \mathrm{ppm}$ during the housekeeping time.

Most probably, the detergents used for cleaning caused higher level of TVOC. Then during the consultation hours it went back to $7 \mathrm{ppm}$.

From the $\mathrm{CO}_{2}$ concentration (Fig. 5.), it can be said that the investigated room was slowly ventilated by the infiltration. The concentration dropped to $900 \mathrm{ppm}$ during the weekend and stayed at this level until Monday and occupant's presence. During the housekeeping time and consultation hours, the concentration rose up to $1550 \mathrm{ppm}$.

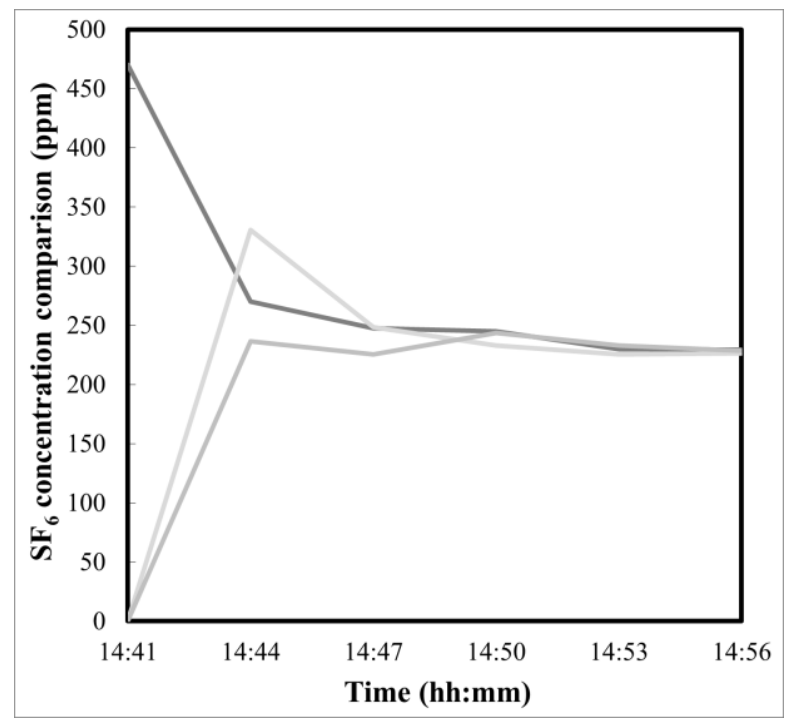

Fig. 8. $\mathrm{SF}_{6}$ concentration comparison: dark grey line monitor standpoint; grey line -windowsill standpoint; light grey line - projection screen standpoint.

\section{Measurements in 3 different standpoints}

The chart (Fig. 8) illustrates 3 different standpoints where measurements were taken. The dark grey line represents the monitor standpoint where the $\mathrm{SF}_{6}$ gas was released first. The tracer gas then expanded to the whole investigated office. Nowadays the use of $\mathrm{SF}_{6}$ has been prohibited in the EU by the EU regulation No. 517/2014. [4]

\section{HYGIENIC EVALUATION OF POLLUTANTS}

In the working environment different risk factors may be present, which also include chemical pollutants. In the Czech Republic, the concentration limits of pollutants are mandatorily prescribed in the working environment. [5], [6], [7], [8]. Employers have general obligations to minimize the negative effects of these harmful factors, which implies the knowledge of nature and degree of risk, it is also necessary to check whether any deterioration is present. The following equation represents the way, how IAQ can be evaluated [9]:

$$
\frac{C_{H C H O}}{P E L_{H C H O}}+\frac{C_{C O}}{P E L_{C O}}+\frac{C_{T V O C}}{P E L_{T V O C}} \leq 1
$$

$\mathrm{C}-$ measured gas concentration [ppm]

PEL - permissible exposure limit [ppm]

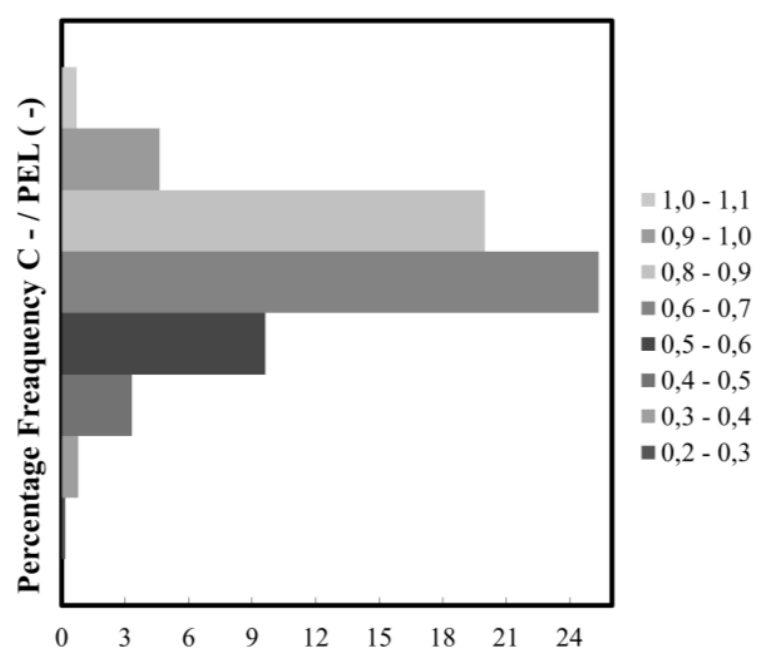

Fig. 9. Percentage Frequency.

The air change was calculated according to the selected pollutants. The measured values of the selected pollutants were averaged. The air changes were calculated according to the following equation [9]:

$$
A C_{\text {poll }}=\frac{\rho_{\text {int,poll }}}{\rho_{\text {max }}-\rho_{\text {ext,poll }}}\left[\frac{1}{h}\right]
$$

$\mathrm{AC}$ - air change $[1 / \mathrm{h}]$

$\rho_{\text {int, poll }}$ - indoor measured averaged concentration of pollutant $[\mathrm{ppm} / \mathrm{h}]$

$\rho_{\max }-$ indoor limit value [ppm]

$\rho_{\text {ent, poll }}-$ outdoor measured value [ppm] 


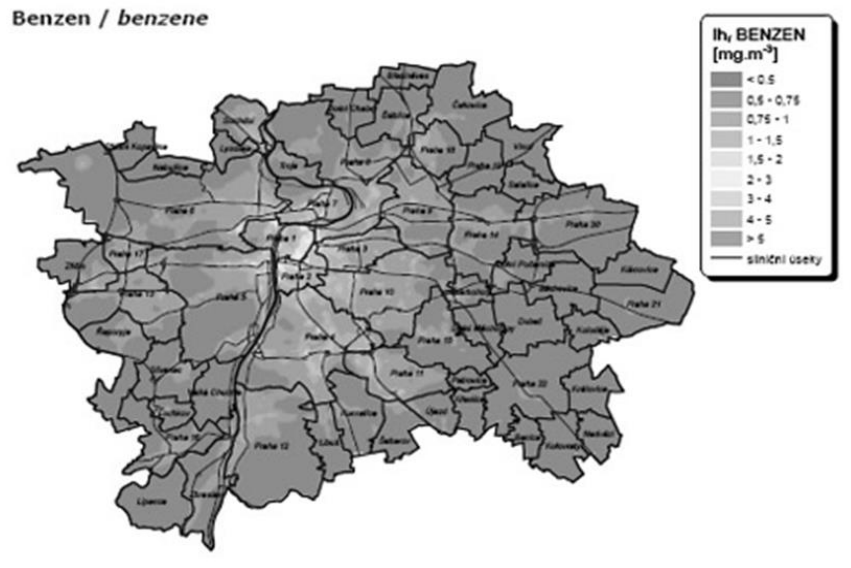

Fig. 10. Benzene variable concentrations in Prague [10].

The air change needed to get rid of the pollutant is equal the above mentioned equation (3). The air change depends on the indoor measured values, outdoor measured values and the maximum allowed indoor concentration value. The outdoor pollutant boundary conditions were taken from Czech Hydrometeorilogical Institute (CHMU) and The National Institute for Public Health (SZU) [10], [11], [12]. The variable concentration values are shown in Fig. 10. The molar mass calculator was used in some calculations. [13]

The conversions of gas units $\left(\mathrm{mg} / \mathrm{m}^{3} ; \mathrm{ppm}\right)$ were calculated according to the following equation [14]:

$$
\frac{X\left[\mathrm{mg} / \mathrm{m}^{3}\right]}{M W} 24,45=Y[\mathrm{ppm}]
$$

$\mathrm{X}$ - gas concentration $\left[\mathrm{mg} / \mathrm{m}^{3}\right]$

$\mathrm{MW}$ - molecular weight $[\mathrm{g} / \mathrm{moll}]$

$\mathrm{Y}$ - gas concentration in [ppm]

In Table II, a summary of the obtained results is given. The highest value was calculated for the TVOC pollution. It is equal to $0.129[1 / \mathrm{h}]$. The negative value for formaldehyde is caused by the boundary conditions where the outdoor concentration was much higher than the indoor concentration according to the source of the measured outdoor data in Prague.

The calculations for carbon dioxide, TVOC and formaldehyde were made. The result for formaldehyde is a negative value because the outdoor concentration taken in the calculation was higher according to CHMU.

\section{CONCLUSION}

The aim of the experiment was to find out an optimal indicator for room ventilation without occupant presence. It is a complicated problem with many boundary conditions. According to the standard [7], the lowest allowed ventilation rate is supposed to be $0.1 \mathrm{1} / \mathrm{h}$ without occupant presence.

After some calculations were made, it was shown that this rate does not have to be sufficient. In respect to the changing boundary conditions, it can be really difficult to generalize. Building occupants, designers and facility managers should stay informed about the indoor and outdoor conditions and control the ventilation system accordingly.

The outdoor conditions can really be variable. On the one hand, in large cities during the rush hours the fresh air rate should be lowered when the building is located close to the highways. Then it is supposed not to be ventilated so much with fresh air. On the other hand, when the building location is suitable, it is needed to increase this minimal ventilation rate up to $0.13 \mathrm{1} / \mathrm{h}$. In my opinion the interesting future of the IAQ lies in these measurements and analysis in the newly renovated houses with air-tight facades or in the low-energy or passive house standard.

\section{INFORMATION ABOUT THE AUTHORS}

\section{Alzbeta Kohoutkova}

She is a Ph. D. student at the Department of Microenvironmental and Building Services Engineering at the Czech Technical University in Prague, Faculty of Civil Engineering, Prague. She specializes in indoor environment and indoor air quality and building energy performance. She works at the University Centre for the Energy Efficient Buildings (UCEEB). She spent 6 months at Denmark Technical University in Lyngby during her Master studies. She writes manuscripts to the professional journals and attends international conferences.

\section{Karel Kabele}

He is a professor and the head of the Department of Microenvironmental and Building Services Engineering at the Czech Technical University in Prague, Faculty of Civil Engineering, Prague. He is the president of REHVA. He deals with the energy systems of buildings (heating, cooling, ventilation, hot domestic water) in terms of their design, computer modelling, simulation and optimization and system interaction with the building.

$\mathrm{He}$ is the author of numerous manuscripts in professional journals, e.g. Energy and Buildings in the field of energy auditing, heating and ventilation systems and energy systems mathematical modelling in buildings. The national calculation tool for building energy performance assessment was developed under his leadership.

In 2007, 2011 and 2013 he was teaching as a visiting professor at the prestigious National University of Singapore. Since 1995 he was awarded with several grants in the internal grant competition, one individual TEMPUS grant and EU grants.

\section{ACKNOWLEDGEMENT}

The authors wish to thank for financial support the following grants: student grant SGS14/011/OHK1/1T/11 and European grant OP VaVpl no. CZ.1.05/2.1.00/03.0091 - University Centre for Energy Efficient Buildings. 
TABLE I

OCCUPATIONAL EXPOSURE LIMITS FOR GERMANY, CZECH REPUBLIC AND OELS BY WHO

\begin{tabular}{|c|c|c|c|c|c|c|}
\hline & & & $\begin{array}{c}\text { Czech Government } \\
\text { Regulation no. } \\
93 / 2012\end{array}$ & & & \\
\hline OELs for Germany & & & PEL & PEL & $\begin{array}{l}\text { STEL } \\
\text { (NPK) }\end{array}$ & $\begin{array}{l}\text { STEL } \\
\text { (NPK ) }\end{array}$ \\
\hline substance & $\begin{array}{l}\text { OEL value } \\
\mathrm{mg} / \mathrm{m}^{3}\end{array}$ & Averaging time & $\mathrm{mg} / \mathrm{m}^{3}$ & ppm & $\mathrm{mg} / \mathrm{m}^{3}$ & ppm \\
\hline formaldehyde & 0.12 & Not determined & 0.5 & 0.37 & 1 & 0.747 \\
\hline toluene & 0.3 & Not determined & 200 & 48.6 & 500 & 121.5 \\
\hline $\begin{array}{l}\text { TVOC (total volatile or- } \\
\text { ganic compound) }\end{array}$ & $0.2-0.3$ & Not determined & - & - & - & - \\
\hline $\begin{array}{l}\text { WHO Air Quality Guide- } \\
\text { lines for Europe Second } \\
\text { Edition (2000) }\end{array}$ & $\begin{array}{l}\text { Guideline values } \\
\text { for individual } \\
\text { substances based } \\
\text { on effects other } \\
\text { than } \\
\text { cancer or } \\
\text { odour/annoyance }\end{array}$ & & PEL & PEL & $\begin{array}{l}\text { STEL } \\
\text { (NPK) }\end{array}$ & $\begin{array}{l}\text { STEL } \\
\text { (NPK) }\end{array}$ \\
\hline substance & $\begin{array}{c}\text { Time - weighted } \\
\text { average value } \\
\mathrm{mg} / \mathrm{m}^{3}\end{array}$ & Averaging time & $\mathrm{mg} / \mathrm{m}^{3}$ & ppm & $\mathrm{mg} / \mathrm{m}^{3}$ & ppm \\
\hline Carbon monoxide & 10 & $8 \mathrm{~h}$ & 30 & 24 & 150 & 120 \\
\hline Carbon monoxide & $30^{\mathrm{c}}$ & $1 \mathrm{~h}$ & 30 & 24 & 150 & 120 \\
\hline Carbon monoxide & $60^{c}$ & $30 \mathrm{~min}$ & 30 & 24 & 150 & 120 \\
\hline Carbon monoxide & $100^{c}$ & $15 \mathrm{~min}$ & 30 & 24 & 150 & 120 \\
\hline formaldehyde & 0.1 & $30 \mathrm{~min}$ & 0.5 & 0.37 & 1 & 0.747 \\
\hline toluene & 0.26 & 1 week & 200 & 48.6 & 500 & 121.5 \\
\hline
\end{tabular}

${ }^{c}$ Exposure at these concentrations should not last longer than the indicated times and should not be repeated within 8 hours.

TABLE II

AIR CHANGE ACCORDING TO SF 6 CONCENTRATION, AIR CHANGE ACCORDING TO THE SELECTED POLLUTANTS

\begin{tabular}{|c|c|c|c|c|}
\hline Selected pollutant & $\begin{array}{c}\text { Air change according to } \\
\mathbf{S F}_{\mathbf{6}} \text { concentration decay }\end{array}$ & $\begin{array}{c}\text { Air change according to } \\
\text { the selected pollutants }\end{array}$ & $\begin{array}{c}\text { Air change } \\
\text { sum }\end{array}$ & $\begin{array}{c}\text { Air change } \\
\text { ranking }\end{array}$ \\
\hline- & $\mathbf{1 / h}$ & $\mathbf{1 / h}$ & $\mathbf{1 / h}$ & - \\
\hline Carbon dioxide $\mathrm{CO}_{2}$ & 0.108 & 0.015 & 0.123 & 2 \\
\hline TVOC & 0.108 & 0.021 & 0.129 & 1 \\
\hline formaldehyde & 0.108 & -0.012 & 0.120 & 3 \\
\hline
\end{tabular}




\section{REFERENCES}

[1] LUMASENSE TECHNOLOGIES. User Manual for Application Software $7620 . \quad 1997 . \quad$ Available: http://innova.lumasenseinc.com/downloads/7620form0/

[2] INNOVA AIR TECH INSTRUMENTS. 1412 Photoacoustic Multi-gas Monitor: User Manual. Innova, 1997.

[3] INNOVA AIR TECH INSTRUMENTS. Ventilation Measurements And Other Tracer - gas Applications, Appendix A, Age of Air Measurement Equations, Concentration decay method: Innova booklet. 1997, p. 29.

[4] Parliament and of the Council of 16 April 2014. Regulation on fluorinated greenhouse gases. Brussels: Official Journal of the European Union, 2014. Regulation (EU) No 517/2014 of the European

[5] EN 14412:2004. Indoor Air Quality, Diffusive samplers the determination of concentrations of gases and vapours.: Guide for selection, use and maintenance. London: British Standard Institute, 2004.

[6] Government directive no. 93/2012. Occupational Health Conditions. Prague: Czech Standards Institute, 2012

[7] CSN 73 0540:2002. Thermal protection of buildings. Prague: Czech Standards Institute, 2002.

[8] World Health Organization. 2000. Air Quality Guidelines for Europe, 2nd Edition. World Health Organization Regional Publications, European Series No. 91. World Health Organization, Regional Office for Europe, Copenhagen, http://www.euro.who.int/document/e71922.pdf.

[9] DRKAL, Frantisek a Vladimir ZMRHAL. CTU IN PRAGUE, Faculty of Mechanical Engineering. Ventilation. Prague: CTU Publisher, 2013. ISBN 978-80-01-05181-8, p. 31.

[10] http://envis.prahamesto.cz/(lhnd3i3kgxyrlb55xrn3y045)/rocenky/Pr11_html/kap_b1.html

[11] http://portal.chmi.cz/files/portal/docs/uoco/isko/grafroc/13groc/gr13cz/ta b/tabIV9-1-1_CZ.html

[12] http://www.szu.cz/uploads/documents/chzp/ovzdusi/konz_dny_a_semin are/2010/09 formaldehyd vysledky.pdf

[13] http://www.convertunits.com/molarmass/

[14] INNOVA AIR TECH INSTRUMENTS, Photoacoustic spectroscopy, Appendix, Units of gas concentration: Innova booklet, 1997, p. 28 